\title{
Solar Operated Electric Power Tiller with Detachable Handle and Wheel
}

\author{
Trikeshwar M Pradhan' ${ }^{1}$, Krishna T Mahule ${ }^{2}$, Vijay Kumar S Patle ${ }^{3}$, Ajay Kumar S Patle ${ }^{4}$, \\ Kamlesh N Rahulkar ${ }^{5}$, Manisha M Nagfasre ${ }^{6}$, Prof. Y. P. Nimje ${ }^{7}$ \\ ${ }^{1-7}$ Department Of Mechanical Engineering, Government Polytechnic Gondia,
}

Received on: 11 December, 2020, Revised on: 11 January, 2021 , Published on: 16 January, 2021

\begin{abstract}
In Indian agriculture, the preparation of seedbed for deep tillage using additional machinery and tilling tools are increased. Power tiller or cultivator is one of the tillage machines most suitable for seedbed preparation. In a power tiller machine the blade is a critical part, which are engaged with the soil to prepare a seedbed and mix to fertilizer. For increasing the maximum weed removal efficiency of tilling blade in new design. There is because to utilize and increase the fertility of land to increasing the crop productivity. In this machine we have added some extra part which is help to improve the maximum weed removal efficiency. The parts are adjustable wheels (for adjusting tilling depth), clearance between two blade etc. Is create a favorable environment for the sustain growth of crop. Commonly used blade shapes are L, J, and C. power tiller is useful for maintaining beds already formed. Power tiller perform both operations like pulverizing and bed maintaining at same time.
\end{abstract}

Keywords - Motor Powered tiller, house gardening, tools, blades, etc..

\section{I- INTRODUCTION}

$\mathbf{N}$ ow a day's Indian farmers are unhappy to spent money for seedbed preparation because of one reason raise in fuel price. To overcome this problem, we made an electric power tiller which is power by electric motor and battery. The battery is ecofriendly and rechargeable. The power tiller is mainly used in agriculture sector for preparing a seedbed on upper layer of soil. The power tiller is not only the higher soil mixing capacity compared with the other machine but also good weed cutting capacity. Power tiller leads to the water air, thermal and nutrient of the soil is improved. In a power tiller we provide an adjustable wheel for various working depths for soil bed preparation. Types of blades are available in market. Just like L, J and C shape of blade.

The power tiller in a market it is operated on IC Engine. For the running of engine the petrol and diesel is needed it is big problem, because the engine creates a pollution in environment and it is very harmful for human beings. Because of this problem we find a solution and make an electric power tiller. This is economical and no any pollution is creates. In electric power tiller we added some more useful accessories, which are adjustable handle is used to adjust the height of handle with respect to operator and adjustable wheel is used to adjust the tilling depth of blades in soil and one more application of wheel is, when it is transport from one place to another place then the total load of machine is on wheel and easily transportable.

One more thing is added in it which is Solar Plate. When battery is discharge in working condition, in this case the solar plate is used for charge the battery and increase the life battery. 


\section{International Journal of Innovations in Engineering and Science, www.ijies.net}

\section{II-DESIGN AND DETAILS OF COMPONENT}

Power tiller is an only one machine which is used to unwanted plant removal in wide row spacing crops. Power tiller blades are used to achieve advantages of better weed removal efficiency and more efficiency inversion and trash mixing.

In power tiller the blades are more critical parts, which are engaged with the soil to prepare a seedbed and mix to fertilizer. When the blades are interact with the soil in a different ways than normal ploughs which are subjected to impact and high friction that creates an unbalancing force on power tiller, that's result to wearing of blades. For increasing the weed removal efficiency and reducing the wearing of blades. The design optimization and manufacturing errors can be minimized by proper design analysis of the components.

Calculation for Designing the Electric Power Tiller

Following are the calculation for the designing of the electric power tiller and similarly gets validate with numerical analysis.

\section{1) FORCES DISTRIBUTION ON THE SHAFT}

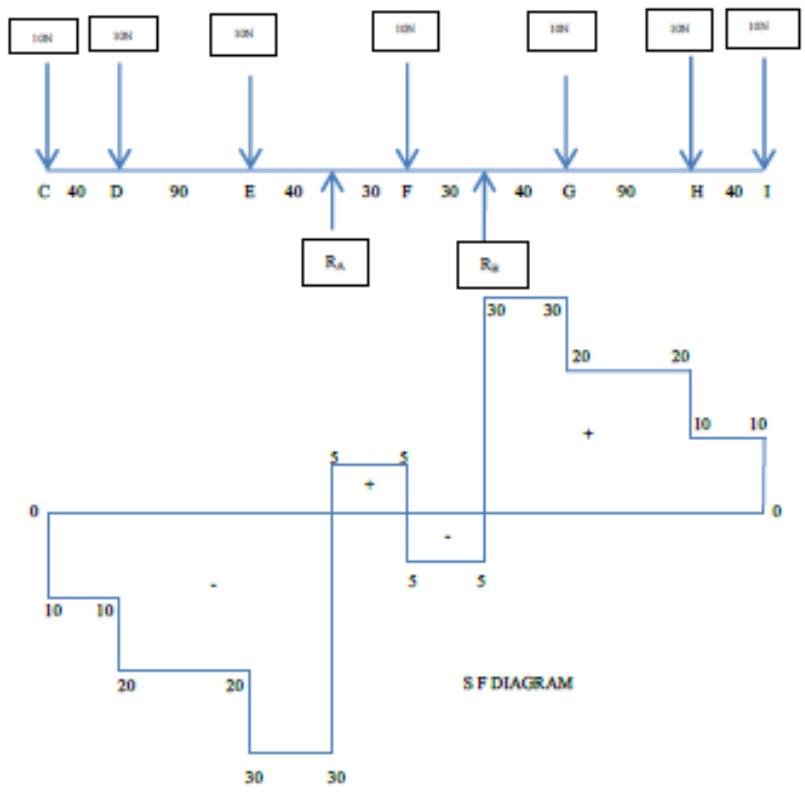

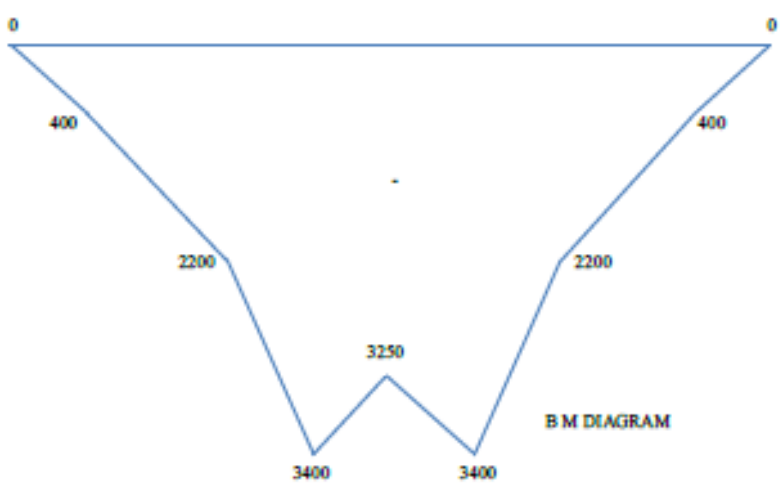

Reaction Calculation

$\mathrm{R}_{\mathrm{A}}+\mathrm{R}_{\mathrm{B}}=70 \mathrm{~N}$

Taking $\sum \mathrm{M} @=0 \mathrm{~N}$

$-(10 \times 170)-(10 \times 130)-(10 \times 40)+(10 \times 30)+(10 \times 100)$

$+(10 \times 190)+(10 \times 230)=60 \mathrm{R}_{\mathrm{B}}$

$\mathrm{R}_{\mathrm{B}}=35 \mathrm{~N} \quad \mathrm{R}_{\mathrm{A}}=35 \mathrm{~N}$

Shear Force Calculation

$\mathrm{SFC}=-10 \mathrm{~N}$

SF D $=-10-10=-20 \mathrm{~N}$

$\mathrm{SF} E=-20-10=-30 \mathrm{~N}$

$\mathrm{SF} A=-30+35=5 \mathrm{~N}$

$\mathrm{SF} \mathrm{F}=5-10=-5 \mathrm{~N}$

$\mathrm{SFB}=-5+35=30 \mathrm{~N}$

$\mathrm{SF} \mathrm{G}=30-10=20 \mathrm{~N}$

$\mathrm{SF} \mathrm{H}=20-10=10 \mathrm{~N}$

$\mathrm{SF} I=10-10=0 \mathrm{~N}$

Bending Moment Calculation

At $\mathrm{C}=0 \mathrm{~N}-\mathrm{mm}$

At $\mathrm{D}=-(10 \times 40)=-400 \mathrm{~N}-\mathrm{mm}$

At $\mathrm{E}=-(10 \times 130)-(10 \times 90)=-2200 \mathrm{~N}-\mathrm{mm}$

At $\mathrm{A}=-(10 \times 170)-(10 \times 130)-(10 \times 40)=-3400 \mathrm{~N}-\mathrm{mm}$

At $F=-(10 \times 200)-(10 \times 160)-(10 \times 70)+(35 \times 30)$

$=-3250 \mathrm{~N}-\mathrm{mm}$

At $\mathrm{B}=-(10 \times 230)-(10 \times 190)-(10 \times 100)+(35 \times 60)$

$-(10 \times 30)=-3400 \mathrm{~N}-\mathrm{mm}$

At $\mathrm{G}=-(10 \times 270)-(10 \times 230)-(10 \times 140)+(35 \times 100)$

$-(10 \times 70)+(35 \times 40)=-2200 \mathrm{~N}-\mathrm{mm}$ 


\section{International Journal of Innovations in Engineering and Science, www.ijies.net}

$$
\begin{aligned}
& \text { At } \begin{aligned}
\mathrm{H}= & -(10 \times 360)-(10 \times 320)-(10 \times 230)+(35 \times 190) \\
& -(10 \times 160)+(35 \times 130)-(10 \times 90)=-400 \mathrm{~N}-\mathrm{mm}
\end{aligned} \\
& \text { At I }=0 \mathrm{~N}-\mathrm{mm}
\end{aligned}
$$

Maximum bending at point $\mathrm{A}$ and $\mathrm{B}$

Maximum bending is 3400

Mild Steel Shaft

1) DESIGN OF SHAFT

TABLE

Properties OF MiLd STEEL SHAFT

\begin{tabular}{|l|c|c|}
\hline Property & Symbol & value \\
\hline Tensile Strength & $\sigma_{\mathrm{t}}$ & $345-525 \mathrm{Mpa}$ \\
Shear Stress & $\tau$ & $200-300 \mathrm{Mpa}$ \\
Ultimate & & \\
Stress/Strength & $\sigma_{\mathrm{ut}}$ & $800-840 \mathrm{Mpa}$ \\
Yield Strength & $\sigma_{\mathrm{yt}}$ & $250 \mathrm{Mpa}$ \\
Bending Sress & $\sigma_{\mathrm{b}}$ & $248 \mathrm{Mpa}$ \\
\hline
\end{tabular}

Combine Twisting and Bending Moment

Transmitting Power $(\mathrm{P})=350 \mathrm{~W}$

Speed $(\mathrm{N})=300 \mathrm{rpm}$

Ultimate shear stress $(\tau)=300 \mathrm{Mpa}$

Ultimate bending stress $\left(\sigma_{\mathrm{b}}\right)=248 \mathrm{Mpa}$

Factor of safety $=8$

Maximum shear stress $\left(\tau_{\max }\right)=\frac{\text { Ultimate shear stress }}{\text { Factor of safety }}$

$$
\begin{aligned}
& =\frac{300}{8} \\
& =37.5 \mathrm{Mpa}
\end{aligned}
$$

Maximum Bending stress $\left(\sigma_{\mathrm{bmax}}\right)=\frac{\text { Ultimate bending stress }}{\text { Factor of safety }}$

$$
\begin{gathered}
=\frac{248}{8} \\
=31 \mathrm{Mpa}
\end{gathered}
$$

a) To calculate torque transmitted by shaft

Power transmitted $\mathrm{P}=\frac{2 \pi \mathrm{NT}}{60}$

$$
\begin{gathered}
\mathrm{T}=\frac{\mathrm{P} \times 60}{2 \pi \mathrm{N}} \\
\mathrm{T}=34.81 \mathrm{~N}-\mathrm{m}
\end{gathered}
$$

Torque $(\mathrm{T})=34.81 \times 10^{3} \mathrm{~N}-\mathrm{mm}$

a) To calculate maximum bending moment Maximum bending moment $\mathrm{M}=3400 \mathrm{~N}-\mathrm{mm}$

b) To calculate diameter of shaft

According to Maximum Shear Stress Theory Equivalent twisting moment is given by,

$$
\begin{aligned}
& \mathrm{T}_{\mathrm{e}}=\frac{\pi}{16} \tau_{\max } \mathrm{d}^{3}=\sqrt{\mathrm{M}^{2}+\mathrm{T}^{2}} \\
& \frac{\pi}{16} \times 37.5 \times \mathrm{d}^{3}=\sqrt{(3400)^{2}+\left(34.81 \times 10^{3}\right)^{2}} \\
& \mathrm{~d}^{3}=\frac{34.97 \times 10^{3}}{7.363} \\
& \mathrm{~d}=16.80 \mathrm{~mm}
\end{aligned}
$$

According to Maximum Normal Stress Theory Equivalent bending moment is given by,

$$
\begin{aligned}
& \mathrm{M}_{\mathrm{e}}=\frac{1}{2}\left[\mathrm{M}+\sqrt{\mathrm{M}^{2}=\mathrm{T}^{2}}\right]=\frac{\pi}{32} \sigma_{\mathrm{bmax}} \mathrm{d}^{3} \\
& d^{\frac{1}{2}\left[3400+\sqrt{(3400)^{2}+\left(34.81 \times 10^{3}\right)^{2}}\right]=\frac{\pi}{32} \times 31 \times} \\
& \mathrm{d}^{3}=\frac{19185}{\frac{\pi}{32} \times 31} \\
& \mathrm{~d}=18.47 \mathrm{~mm} \approx 20 \mathrm{~mm}
\end{aligned}
$$

Diameter of shaft is $20 \mathrm{~mm}$

\section{1) VELOCITY RATION OF CHAIN DRIVE}

$\mathrm{N}_{1}=$ Rated speed of motor $=300 \mathrm{rpm}$

$\mathrm{N}_{2}=$ Speed of shaft

$\mathrm{T}_{1}=$ Teeth on small sprocket $=9$

$\mathrm{T}_{2}=$ Teeth on big sprocket $=28$

$$
\frac{\mathrm{N}_{1}}{\mathrm{~N}_{2}}=\frac{\mathrm{T}_{2}}{\mathrm{~T}_{1}}
$$




\section{International Journal of Innovations in Engineering and Science, www.ijies.net}

$$
\begin{gathered}
\frac{300}{\mathrm{~N}_{2}}=\frac{28}{9} \\
\mathrm{~N}_{2}=96.42 \mathrm{rpm}
\end{gathered}
$$

\section{2) MOTOR AND SPECIFICATION}

\section{Geared Motor}

Voltage - 24 VDC

Rated Current -20 A

Output Watt -350

Rated Speed - 3000 rpm

After Reduction - 300 rpm

Teeth on sprocket -9
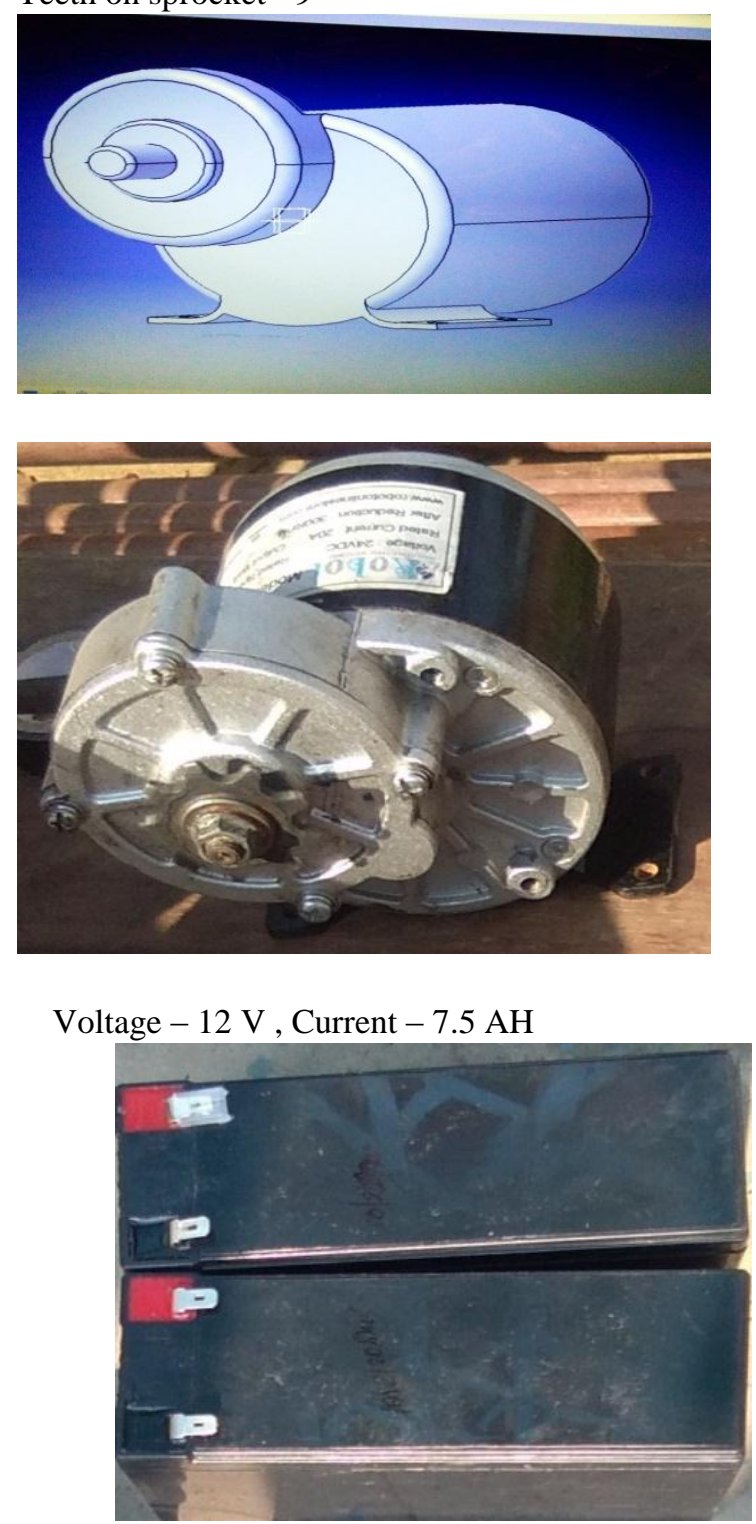

2) BLADES AND SPECIFICATION

Shape of blade $-\mathbf{J}$ shape

No. of flange -2

No. of blade on one flange -4

Thickness of blade $-4 \mathrm{~mm}$

Cutting edge thickness $-2 \mathrm{~mm}$

Length of blade $-110 \mathrm{~mm}$

Outer diameter of hub $-26 \mathrm{~mm}$

Inner diameter of hub $-20 \mathrm{~mm}$

Hole on hub - One hole of $9 \mathrm{~mm}$

Split pin diameter $-9 \mathrm{~mm}$

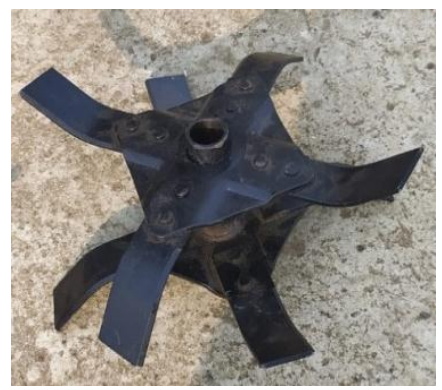

3) FRAME

Length $-400 \mathrm{~mm}$

Breadth $-250 \mathrm{~mm}$

Height $-25 \mathrm{~mm}$

Thickness $-3 \mathrm{~mm}$

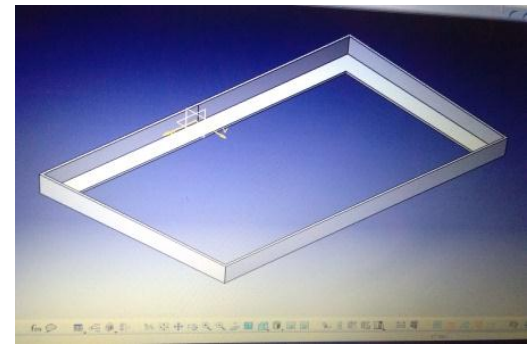

4) AdJustable WHEEL

Outer diameter $-200 \mathrm{~mm}$

Bore diameter $-15 \mathrm{~mm}$

Thickness $-50 \mathrm{~mm}$

It is adjusted three times, the distance between the holes is

$50 \mathrm{~mm}$. It is depends on the tilling depth. 


\section{International Journal of Innovations in Engineering and Science, www.ijies.net}

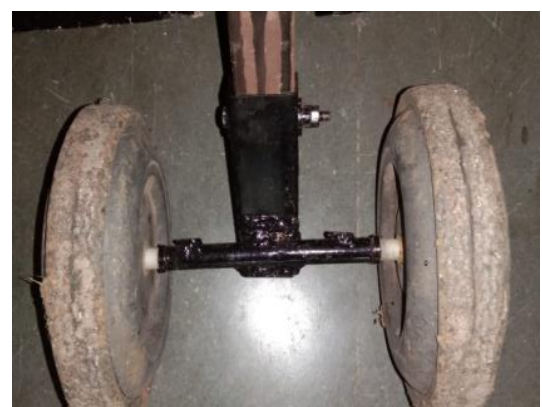

\section{5) ADJUSTABLE HANDLE}

Diameter of handle pipe $-35 \mathrm{~mm}$

Diameter of small pipe $-33 \mathrm{~mm}$

Hole on pipe $-10 \mathrm{~mm}$

Distance between three holes $-50 \mathrm{~mm}$

It is adjust the height according to require.

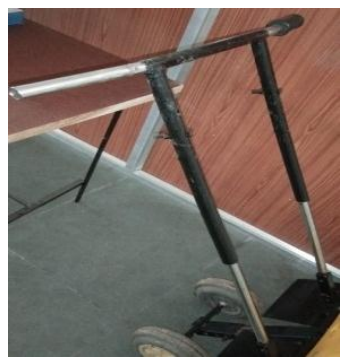

6) SHAFT AND SPECIFICATION

Material of shaft - mild steel

Diameter of shaft $-20 \mathrm{~mm}$

Length $-400 \mathrm{~mm}$

Teeth of sprocket -28

Sprocket mounted at a center of shaft

7) Controller

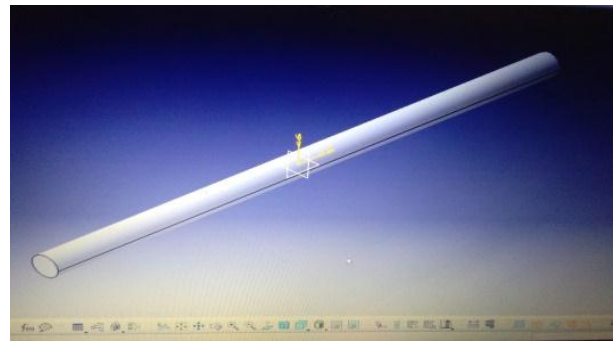

Body material - Aluminum

Cable length $-100 \mathrm{~mm}$

\author{
Rated power $-350 \mathrm{~W}$ \\ Current limit - 33 A \\ Rated voltage -24 v DC
}

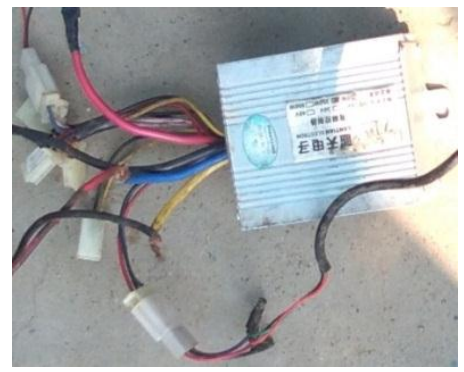

8) Solar Plate

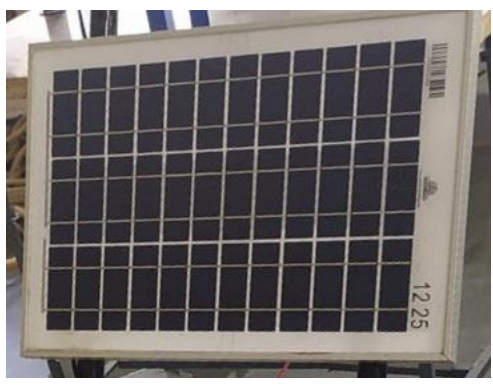

\section{III-CONSTRUCTION}

The electric power tiller is consisting of three major components which are battery, motor and blades. Battery and motor are mounted on the frame and blades are mounted on shaft below the chassis. The main shaft is rotated by rotational motion of motor shaft, the power transmitted by sprocket and chain mechanism. In the power tiller we adjust the height of handle for human being. We also give the adjustment in wheel for maintaining the tilling depth of blades in soil. The solar plate also added in it to charge the battery, because some time us not able to charge the battery with electricity. That time the solar plate is useful.

\section{IV-WORKING MECHANISM}

The electric power tiller work on motor power. The blades powered from the Direct Current Motor, the gear mount on motor shaft is with 9 teeth and the gear mount on main shaft is with 28 teeth. Hence the speed decreases and torque increases. Speed of motor $300 \mathrm{rpm}$ and the speed of main shaft is $100 \mathrm{rpm}$. The blades rotate with $96 \mathrm{rpm}$ and torque is $33.42 \mathrm{Nm}$. It is adjustable depth of tilling by the 


\section{International Journal of Innovations in Engineering and Science, www.ijies.net}

adjustment of wheel and also its height is to be adjusted by adjusting the handle. The solar plate is used to charge the battery. The speed is fully controlled by throttle. It is renewable and economical.

\section{V-TESTING AND RESULTS}

Electric power tiller remove weeds with roots and destroy it, this also used to mixing the fertilizer with soil. The tilling depth is adjustable with the help of wheel, tilling depth up to $70-80 \mathrm{~mm}$. the fully charged battery run $30-$ 40 minutes and with solar plate it run $60-70$ minutes.
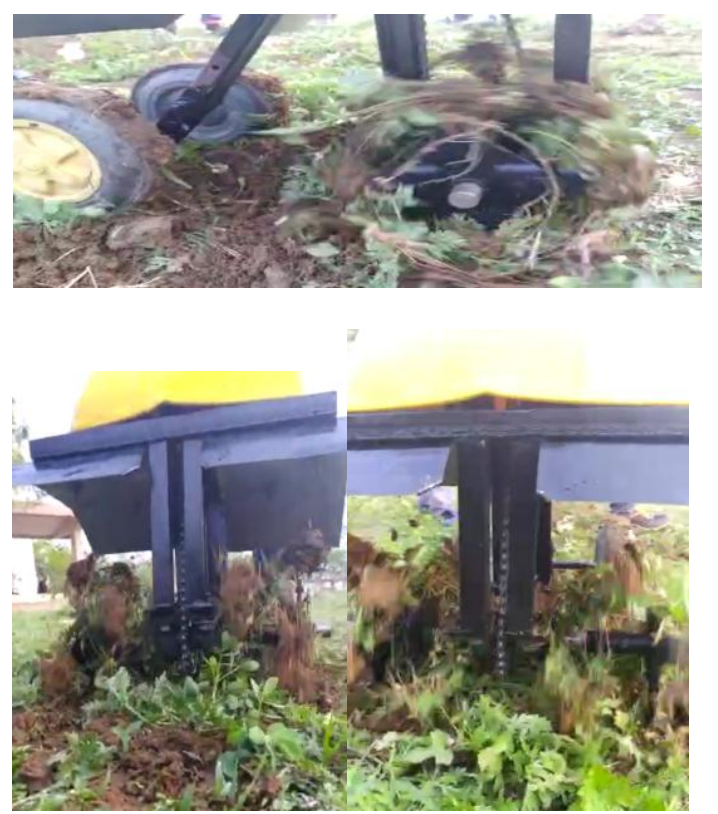

VI- MOdel OF Electric PoWer Tiller

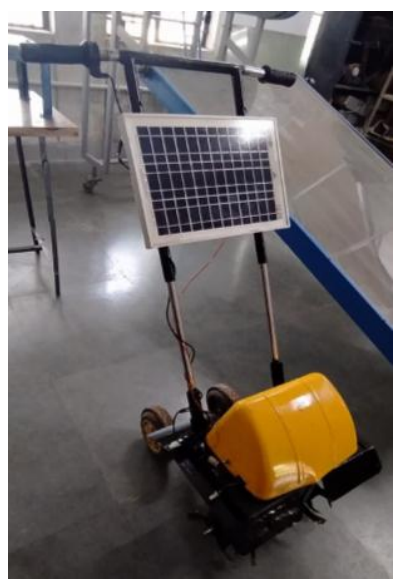

\section{VII-CONCLUSION}

Our project is solar operated electric power tiller; it is implemented for emphasis on minimization of harmful efforts of using the manual power tiller. We made it in college workshop. The power tiller with a new design and operated by electric motor and battery. We were referring most of the referral matters to successfully done our project on our best level.

Electric power tiller is actually solar operated means its renewable type as such that which will be advantageous for future agricultural site.

\begin{tabular}{|c|c|}
\hline Parameter & Solar operated electric power tiller \\
\hline \multirow{2}{*}{$\begin{array}{c}\text { Time required to } \\
\text { remove weeds in } \\
450 \text { square feet } \\
\text { area }\end{array}$} & At low speed $(60 \mathrm{rpm})-40 \mathrm{mins}$ \\
\hline & At high speed $(96 \mathrm{rpm})-30 \mathrm{mins}$ \\
\hline Depth of blade & $70 \mathrm{~mm}$ \\
\hline Charging time & $\begin{array}{l}\text { 1. } 40 \text { mins with AC supply of } \\
240 \text { volts } \\
\text { 2. } 8 \mathrm{hrs} \text { with average sun light } \\
\text { intensity of } 1 \mathrm{Kw} / \mathrm{m}^{2}\end{array}$ \\
\hline
\end{tabular}

\section{REFERENCES}

[1] Haruo Sakamoto, Development of an Electric Power Tiller for House Gardening, Department of Intelligent Mechanical Systems Engineering, Kochi University of Technology,

[2] Akshay lede ${ }^{1}$, Amit Girhepunje ${ }^{2}$, Dhiraj Tirpude ${ }^{3}$, Naresh Dadmal, ${ }^{4}$ Sandip Wanjari, ${ }^{5}$ Sumit Gajbhiye ${ }^{6}$, Chhotelal Chafle ${ }^{7}$ [2018]. Modification of rotavator and bed re-maker. 1, 2, 3, 4, 5, 6 be students, 7assistant professor, mechanical department, Manoharbhai Patel institute of engineering and technology, bhandara, Nagpur university. (India)

[3] Prof. N.A.Ghanokar ${ }^{l}$ \& Prof. S. P. Pawar ${ }^{2}$. Computer aided design and analysis of rotary tillage tool component for failure. 1, 2 assistant professor, department of mechanical engineering, mgi-coet shegaon, India 


\section{International Journal of Innovations in Engineering and Science, www.ijies.net}

[4] Vignesh. $M^{1}$, Dr. Muruganandhan. $R^{2}$, Dasari. $N^{3}$, Nagarajan. $M^{4}$ [2015], Study of torsional response on the rotor shaft of a rotavator under transient load conditions. final year pg student, engineering design division, department of mechanical engineering, college of engineering, guindy, chennai, tamilnadu, india.

[5] Mr. Mahesh Gavali, Mr. Satish Kulkarni [2014], Development of rotary weeder blades by finite element method, pg student, textile and engineering institute, ichalkaranji, Maharashtra . Professor, mechanical engg, Pvpit College of engg. Budhgaon, Maharashtra.

[6] C. Manivelprabhu ${ }^{l}, d r . \quad N$. Sangeetha $^{2}, \quad T$ .Ramganesh ${ }^{3}$ [2015], Design modification and structural analysis of rotavator blade by using hyper works $12.0,1$ associate professor kumaraguru college of technology coimbatore641049 manivel135@gmail.com, 2 senior associate professor kumaraguru college of technology coimbatore- 641049 sangeetha.n.mec@kct.ac.in, 3 project engineer kumaraguru college of technology coimbatore641049

[7] Mandal $S^{1 *}$, Bhattacharyya $B^{2}$ And Mukherjee $S^{l}$ [2015], Design of rotary tiller's blade using specific work method (swm), 1csir-central mechanical engineering research institute, durgapur, west bengal 713209, India 2bengal engineering and science university, howrah, India.

[8] Jeevarathinam.A, Velmurugan.C , Design modification and analysis of rotavator blade. Mechanical engineering, kumaraguru college of technology/anna university, India.

[9] Subrata Kumar Mandal, Basudeb Bhattacharyya, Somenath Mukherjee and Ashok Kumar Prasad [2016], Design optimization of rotary tiller blade using specific energy requirement. csir-central mechanical engineering research institute, durgapur, India. Indian institute of engineering science and technology, howrah, India.

[10] M. Veerangouda, E. R. Sushilendra, M. Anantachar [2011], Development and evaluation of multipurpose tool carrier for power tiller. Dept. Of farm power and machinery, college of agricultural engineering raichur - 584 102, karnataka, india, email: m.veerangouda@rediffmail.com .

[11] Sirisak Chertkiattipol , Tanya Niyamapa , Wanwisa Jantaradach , And Kridsada Saensuwan [june 2008], The performance of rotary power tiller using prototype rotary blades in dry. landfield. Department of agricultural engineering, faculty of engineering at khamphaengsaen, Kasetsart University, 73140, thailand, corresponding author, e-mail: chertkiattipol@hotmail.com .

[12] Hemad Zareiforoush ${ }^{1}$,*, Mohammad Hasan Komarizadeh, Mohammad Reza Alizadeh ${ }^{2}$, Rotary Tiller Design Proportional to a Power Tiller using Specific Work Method (SWM). Department of Mechanical Engineering of Agricultural Machinery, Faculty of Agriculture, University of Urmia, P.O. Box 165, Urmia 57135, Iran .Research Institute of Iran (RRII), P.O. Box 1658, Rasht 41235, Iran. 